\title{
SPENT NUCLEAR FUEL DRY STORAGE: STATUS AND CURRENT ISSUES
}

\author{
M.V. Yatsenko, A.V. Korolyov \\ Odessa National Polytechnic University, Odessa, Ukraine \\ E-mail: yatsbb@gmail.com, tel.+38-095-725-02-22
}

\begin{abstract}
Among all the options of spent nuclear storage, dry storage seems to be the most expedient method for the nearest future all over the world. Despite the economic attractiveness and the presence of a positive operating experience, there are still open questions. In this article author investigates the status of dry storage, gives a review of world experience and current issues that need to be solved to ensure safe long-term storage of spent nuclear fuel.
\end{abstract}

PACS: $28.41 . \mathrm{Kw}$

\section{INTRODUCTION}

Ensuring safety during spent nuclear fuel storage process is a one of the essential factors for the further stable development of nuclear energy.

The increasing volume of spent nuclear fuel assemblies requires the commissioning of a larger number of new storages of spent nuclear fuel, optimizing the process of obtaining a license for commissioning facilities, as well as extending the licenses of already operating facilities. In turn, the current trend goes towards an increase in the initial enrichment of nuclear fuel, the elongation of the fuel rod, which, along with an increase in the burnup, leads to an increase in the residual heat release. In particular, the maximum design burnup for the latest generation of light-water reactors (up to $\sim 65 \mathrm{MWd} / \mathrm{t}$ of uranium and more) is $30 \ldots 40 \%$ higher than the initial indicators of the structures put into operation in the 1970-1980s, and the design enrichment level of fresh fuel close to $5 \%$. To work with such SNF, it is necessary to develop and create storage systems with a greater thermal capacity, improved nuclear and radiation protection features.

The development of reactor technologies, the emergence of modular reactors, the introduction of which will enhance the number of SNF storage sites, will further increase the need for R \& D in terms of dry storage of SFA.

In this paper, the author presents the current state of dry storage of spent nuclear fuel in the world, and describes the problems that engineers need to solve in order to improve the technology of storage of SNF in the future.

\section{GLOBAL SNF STORAGE OVERWIEW}

The majority of States have adopted the policy of direct disposal of spent fuel, while several States with the largest nuclear programs (France, China, Japan, the Russian Federation, and the United Kingdom) have adopted the policy of reprocessing nuclear fuel and recycling the separated material. With no permanent disposal facility for spent nuclear fuel anywhere in the world, more than 50 countries keep spent fuel in storage awaiting reprocessing or disposal.

There are about 10.000 tHM of spent fuel discharged per year worldwide [1].

USA. The first dry storage installation was licensed by the NRC in 1986 at the Surry Nuclear Power Plant in Virginia. Now every U.S. nuclear reactor site except for
TMI-1, Shearon Harris, and Wolf Creek either has dry storage implemented or has near-term plans to implement dry storage. Currently, 79 ISFSIs are licensed in the U.S.

This number includes the five sites that have both a general and a site-specific ISFSI license as two ISFSIs, and includes the PFS facility (which has a license but has never operated), the TMI-2 facility in Idaho, and the DOE Idaho spent fuel facility.

Three new ISFSIs started operating in 2016 at V.C. Summer, Watts Bar, and Clinton. One new ISFSI began operating in 2017 at Crystal River 3. Loading operations began in June and by mid-January, 2018, all 39 NUHOMS 32PTH1 DSCs had been placed into service. South Texas Project is planning to have an ISFSI in operation in 2019.

Moreover, considering the non-availability of dry spent nuclear storages at some sites and the location of others in the most densely populated areas of the U.S., Holtec International, U.S. dry cask supplier, proposed creation of Consolidated Storage facility, and submitted an application to that extent in March 2017. The facility, named the HI-STORE, would be located near Carlsbad, New Mexico. An underground Vertical Ventilated Module (VVM) named HI-STORM UMAX is to be used as a storage system. Holtec plans to build its CISF in up to 20 phases with a potential total capacity of 100000 tHM [3].

Generally, there are more than 113000 spent nuclear assemblies stored in more than 2700 casks over the USA. The main players in the market are such companies as Foratome's TN, Holtec International, NAC International.

Because of future decommissioning of a large number of units, delays in final disposal program, and plans to commission small modular reactors, that would cause an increase in quantity of new casks, the dry storage technology in the U.S. will continue to grow steadily for the next several decades.

Germany. The German facilities for the long-term storage of SF come down to the centralized dry storage facilities in Ahaus and Gorleben, 12 on-site storage facilities with 1435 storing positions and the local intermediate storage facilities at Greifswald (ZLN) and Jülich. All stationary storage facilities commissioned in the period 2002-2007 and have 40-year operating licenses. All centralized storage facilities started operating in 1992, 1995, and 1999 [4]. 
Currently more than 1000 casks are stored in all storage areas. The main suppliers of casks are GNS with CASTOR and COSTOR casks and Foratome TN casks.

Since Germany's geological disposal project is still in the course of development, there is a problem of extending the lifetime of the interim storages licenses. For example, licenses for the following storages will expire: TBL Gorleben in 2034, onsite storage Lingen in 2042. Therefore, we can conclude that in the nearest future Germany is expected to extend the current licenses for the operation of interim storages. For these purposes, it is necessary to continue research and development programs related to dry storages and launch aging management programs.

Ukraine. There are 15 PWR (WWER) units in operation. For the six of them the dry storage facility was created at the Zaporizhzhya NPP site. The interim spent nuclear fuel facility at Zaporizhzhya NPP is the very first facility of such type in Ukraine and has operation license for 50 years of storage. The storage facility is designed to store about 9.200 SFAs in 380 containers. Technology involves storing SFA in a vertical concrete cask (VSC-24) [5].

For the SNFA from other nine units a closed nuclear fuel cycle is implemented, in which SNF is transported to the reprocessing plants in Russia and valuable products and high-level waste are returned.

A wet pool-type storage facility (ISF-1) exists at the site of the Chernobyl NPP. Since 2001 the construction of a dry storage facility for the Chernobyl nuclear power plant has been underway. The Interim Spent Nuclear Fuel Dry Storage Facility (ISF-2) is necessary for storage or storage and packing of about 21000 SFA, 2 thousand spent additional absorbers and more than 23000 extension rods, transported from ChNPP Units 1 , 2,3 , and from "wet" type ISF-1.

This project uses Holtec International technology, namely Double Wall Canister (DWC) which is stored in a horizontal concrete module [6].

The construction of the Centralized storage of spent nuclear fuel from WWER reactors in the exclusion zone commenced in Ukraine in the beginning of 2015. This facility will also apply the technology of Holtec International. Multipurpose Canister (MPC) will be loaded with 31 WWER-1000 SFA or 85 WWER-440 SFA. Using HI-TRAC transfer cask MPC will be loaded into the HI-STAR transport cask and will be transported horizontally to storage site. The in cask receiving building, MPC will be transferred to the HI-STORM vertical concrete storage system. Storage facility has 100 years operation license. It is planned to store 16529 SFAs in 480 HI-STORM casks at the site [7].

Given the large amount of spent nuclear fuel and the refusal to export it to the Russian Federation, it can be concluded that the volume of stored SFA in the casks will be increased. Ukraine does not have national R \& D programs for dry storage, and it is vital to start researching and accumulating international experience to provide safe and reliable long-term storage.

\section{CURRENT ISSUES}

From the previous section, it is clear that in the current situation, interim dry storage of spent nuclear fuel is the main option for managing spent nuclear fuel in the world today. Below are the main key issues and priorities of additional research of Extended Storage for ensuring safety during long-term storage period.

Thermal profiles. The temperature experienced by SNF during dry storage depends on factors such as decay heat and cask design parameters. The study of temperature fields throughout the storage period plays an important role, especially at the stage of SNF loading and transportation. During the irradiation in reactor core fuel reaches a temperature of up to $350{ }^{\circ} \mathrm{C}$. After it is discharged into the pool, temperature falls up to $70{ }^{\circ} \mathrm{C}$, and in the process of unloading SNF onto the canister, peak cladding temperatures rise up due to exclusion of water. In the process of drying and filling the canister, the temperature changes immensely, also affecting the fuel rod. As far as the main degradation mechanisms depend on temperature (e.g., $\mathrm{Zr}$ cladding hydride reorientation and embrittlement), creation of the accurate temperature distribution models and their validation for the processes of preparing fuel for storage and transportation will allow, along with the creation of less conservative temperature distributions for storage, to determine the exact data for predicting the degradation effects that may occur in the long term perspective $[8,9]$.

Stress profiles. In view of the fact that many of the fuel degradation mechanisms, such as cladding stress from decay gas production, delayed hydride cracking, embrittlement (for high burnup fuel) lead to rod failure, structural analyses for normal, off-normal, and accident conditions for storage and transportation must be performed taking into account the effect on the degradation of the components of cask and fuel [10, 11]. During analyses, especially long-term storage and accident condition analyses, it is necessary to use already degraded material conditions instead of undegraded material. In order to perform a fuel retrievability evaluation it is crucial to carry out a structural analysis with different burnup levels for the operations of transfer and transportation after unloading SNF from the cask after storage, taking into account the prolongate storage time. Models for these purposes, models using different types of stress and degraded material properties are needed.

Drying process. This operation is used to remove moisture from used fuel and inner space of canister [12]. During this operation maximum fuel cladding temperature must remain sufficiently low to avoid (a) dissolution of circumferential hydrides that exist in the cladding and (b) high gas pressures within the fuel rods, which lead to high cladding hoop stress. It is necessary to develop and implement realistic experimental models and installations to determine the maximum fuel cladding temperature during the drying operation. The second issue is the moist that could remain after drying. Even if proper drying procedures are followed, some water could remain, given the tortuous path water may follow, in addition to the contribution from physisorbed and chemisorbed water that may not be removed in the process of drying. A separate issue is the drying of untight fuel rods or damaged SFA. For such a case, it is necessary to determine the drying time, the gas 
temperature, and also to ensure the protection of personnel in case of an increase in activity around the cask.

\section{CONLUSIONS}

Summarizing all information below, we can conclude that all leading countries in nuclear power sector are currently using dry spent nuclear fuel storage technology. Regardless of the future plans of these countries for the development of nuclear energy, the volume of stored fuel as well as the number of storage sites will increase. From the experience of some countries it is clear that, among other things, it is necessary to prepare the public to accept this fact. Additionally, during the design of modern dry storage systems it should be taking into account the increased lifetime of such systems.

Despite the absence of the obvious disadvantages of this storage technology, there are some crucial directions to work on. Solving issues related to thermal storage regimes, stress profiles, transportation and retrieval questions, will influence not only safety, but also allow optimizing the dry storage procedure, increasing the term of fuel storage, resolving issues related to final disposal or reprocessing after storage of SNF.

The development of national $\mathrm{R} \& \mathrm{D}$ programs related to long-term storage of SNF as well as storage of high burnup fuel will help during the planning of development of nuclear energy, optimize the use of funds, and simplify interaction with the regulatory body.

\section{REFERENCES}

1. Status and Trends in Spent Fuel and Radioactive Waste Management. 2018 edition // IAEA Nuclear Energy Series. No. NW-T-1.14. IAEA, Vienna.

2. C. Greene. An Overview of Spent Fuel Storage in the US // INMM Spent Fuel Management Seminar. Alexandria, USA, 22-24 January, 2018.
3. https://holtecinternational.com/productsandservic es/hi-store-cis (accessed 12.01.18).

4. A. Jussofie. Spent Fuel Management and Storage in Germany // International Seminar on Interim Storage of Spent Fuel. Tokyo, Japan: 15-17 November, 2010.

5. Y. Pechera. Spent Fuel Storage Facility of Zaporizhzhya NPP, Creation, Licensing, Operation // International Conference on Storage of Spent Fuel From Power Reactors. Vienna, Austria, 2-6 June, 2003.

6. https://chnpp.gov.ua/en/184-projects/currentprojects/434-2434 (accessed 12.01.18).

7. M. Yatsenko. Central Spent Fuel Storage Facility (CSFSF) safety assessment aspects // IAEA Technical Meeting on Development of an Approach to Define Generic Test Conditions for Dual Purpose Casks, Vienna, Austria: 2-6 October, 2017.

8. Used Nuclear Fuel Storage and Transportation Data Gap Prioritization // FCRDUSED-2012-000109 Draft, PNNL-21360, Prepared for the U.S. Department of Energy Used Fuel Disposition Campaign. Washington, USA, 2012.

9. J.-S. Kim, J.-D. Hong, Y.-S. Yang, D.-H. Kook. Rod internal pressure of spent nuclear fuel and its effects on cladding degradation during dry storage // Journal of Nuclear Materials. 2017, v. 492, p. 253-259.

10. Y.S. Kim. Delayed hydride cracking of spent fuel rods in dry storage // Journal of Nuclear Materials. 2008, v. 378, p. 30-34.

11. H. Alsaed. Extended Storage and Transportation Gap Analysis Update - 5 Year Delta // SFWST Annual Group Meeting. Las Vegas, USA: 22-24 May, 2018.

12. W.S. Large. Review of Drying Methods for Spent Nuclear Fuel, WSRC-TR-97-0075. Savannah River Site, 1997, 39 p.

\title{
СУХОЕ ХРАНЕНИЕ ОТРАБОТАВШЕГО ЯДЕРНОГО ТОПЛИВА: СОСТОЯНИЕ И АКТУАЛЬНЫЕ ПРОБЛЕМЫ
}

\author{
М.В. Яценко, А.В. Королёв
}

Среди всех вариантов хранения отработавшего ядерного топлива сухое хранение представляется наиболее целесообразным методом в ближайшем будущем во всем мире. Несмотря на экономическую привлекательность и наличие положительного опыта работы, остаются открытые вопросы. В этой статье автор исследует состояние сухого хранения, дает обзор мирового опыта и текущих проблем, которые необходимо решить, чтобы обеспечить безопасное долгосрочное хранение отработанного ядерного топлива.

\section{СУХЕ ЗБЕРІГАННЯ ВІДПРАЦЬОВАНОГО ЯДЕРНОГО ПАЛИВА: СТАН І АКТУАЛЬНІ ПРОБЛЕМИ}

\section{М.В. Яценко, О.В. Корольов}

Серед усіх варіантів зберігання відпрацьованого ядерного палива сухе зберігання представляється найбільш доцільним методом у найближчому майбутньому в усьому світі. Незважаючи на економічну привабливість і наявність позитивного досвіду роботи, залишаються відкриті питання. У цій статті автор досліджує стан сухого зберігання, дає огляд світового досвіду і поточних проблем, які необхідно вирішити, щоб забезпечити безпечне довгострокове зберігання відпрацьованого ядерного палива. 